\title{
KANDUNGAN UNSUR FLUORIDA PADA EMAIL GIGI TETAP MUDA YANG DI TUMPAT SEMEN IONOMER KACA DAN KOMPOMER
}

\author{
Eva Fauziah, Ismu S Suwelo, Hendarlin Soenawan \\ Departemen Ilmu Kedokteran Gigi Anak \\ Fakultas Kedokteran Gigi Universitas Indonesia
}

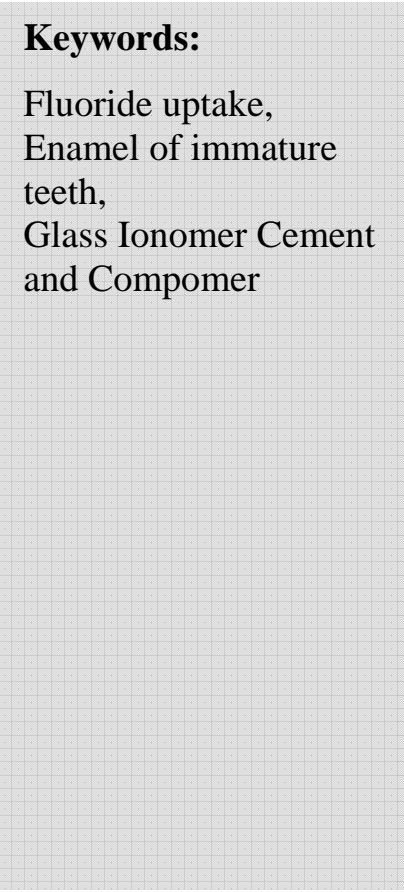

\begin{abstract}
The purpose of this study was to determine the fluoride uptake in enamel of young permanent teeth between Glass Ionomer Cement and Compomer filling. The subject for this study was 21 premolar, and each tooth divided into 2 parts. The first part filled with Glass Ionomer Cement (Fuji IX ART,GC), and the second part filled with Compomer (Dyract, Denstsply), so the samples were 21 Energy Dispersive X-Ray Spectrophotometry analysis of Glass Ionomer Cement and 21 Energy Dispersive XRay Spectrophotometry analysis of Compomer. Using t-test the fluoride uptake in the enamel of young permanent teeth with Glass Ionomer Cement and Compomer filling was significantly increased $(t=3,705 \mathrm{p}=0.001)$. The increasing of fluoride uptake in the enamel of young permanent teeth with Glass Ionomer Cement filling is more high than Compomer. This study also showed fluoride uptake from Glass Ionomer Cement and Compomer which exhibited in enamel of young permanent teeth was significantly different $(\mathrm{t}=3,705 \mathrm{p}=0.001)$. Fluoride uptake of Glass Ionomer Cement filling in enamel of immature teeth was much more compare to Compomer.
\end{abstract}

\section{Pendahuluan}

Email merupakan struktur keras dalam tubuh. Kandungan email terdiri dari 96\% bahan inorganik dan $4 \%$ air, bahan organik serta jaringan fibrosa. Bahan inorganik ini terdiri beberapa juta kristal hidroksi apatit yang mempunyai rumus kimia Ca10(PO4)6(OH)2. Termasuk juga terlihat jelas sejumlah 
karbonat(4\%), sodium(0,6\%), magnesium $(1,2 \%)$, klorida $(0,2 \%)$ dan sejumlah kecil fluorida $(0,01 \%)$. Fluorida terutama terdapat pada permukaan enamel. ${ }^{1,2}$

Bagian dari email meliputi enamel rod dan rod sheath. Enamel rod atau prisma email merupakan struktur utama dari email yang terbentuk dari kristal-kristal hidroksiapatit. Rod sheath merupakan bagian luar enamel rod yang sebagian besar merupakan substansi fibrosa organik. $^{1,2} \quad$ Email pada gigi mempunyai ketebalan yang berbeda pada tiap bagian dan bervariasi diantara jenis gigi, maksimum 2,5 mm. Pada gigi permanen emailnya lebih tebal dari gigi sulung. Hal ini disebabkan karena terjadinya proses remineralisasi sehingga kandungan mineral pada email gigi permanen lebih banyak dibandingkan gigi sulung. 3,4 Email gigi sulung kurang termineralisasi hal ini juga menjelaskan mengapa warna gigi sulung lebih opak. ${ }^{5}$

Setelah sekresi email yang terakhir, email yang sudah terbentuk lengkap masih belum termineralisasi secara sempurna. Penyelesaian mineralisasi terjadi setelah 2-3 tahun erupsi, yaitu proses maturasi email. ${ }^{6}$ Proses ini sangat kompleks dimana protein dan air di email dikeluarkan bersamaan dengan penyerapan kalsium dan fosfat. Penyerapan ion kalsium dan fosfat dipengaruhi oleh konsentrasi, laju difusi, dan nilai $\mathrm{pH}$ pada saat itu. ${ }^{6,7}$ Ion fluorida mempunyai peran dalam proses demineralisasi dan mineralisasi. ${ }^{6}$ Bahan restorasi gigi harus dipilih secara tepat dan cermat sesuai dengan indikasinya. Untuk gigi sulung dan gigi tetap muda bahan yang sering digunakan adalah Glass Ionomer Cement (Semen Ionomer Kaca=SIK) dan Compomer (Kompomer). ${ }^{8,9,10,11}$ Semen Ionomer Kaca mempunyai komposisi bahan bubuk acid soluable calcium fluoraluminosilicate glass dan cairan aqueous solution of polyacrilyc acid. Kandungan fluorida pada bahan ini sangat tinggi, fluorida tersebut berfungsi untuk memperendah suhu fusi kaca, meningkatkan kekuatan dan translusensi semen. ${ }^{9,12,13}$ Kompomer adalah bahan restorasi dengan kombinasi keuntungan antara bahan Resin Komposit dan Semen Ionomer Kaca. ${ }^{14}$
Keuntungan dari SIK yaitu perlekatan ionik permanent terhadap struktur gigi dan kapasitas untuk melepaskan fluorida. ${ }^{9}$ SIK memiliki biokompabilitas yang baik terhadap jaringan gigi, solubilitas rendah, antikariogenik, perubahan deimensi kecil dan tahan terhadap fraktur. Sedangkan kerugiannya antara lain adalah translusensi, estetik, kehalusan permukaan, compressive strength, flexural strength kurang dibandingkan Kompomer dan juga lebih tidak tahan terhadap erosi. ${ }^{13}$

Pelepasan fluorida SIK didahului oleh reaksi setting. Reaksi SIK merupakan reaksi asam basa antara acidic polielektrolit dengan aluminosilicate glass.(Gambar 1) Polyacid kemudian bereaksi dengan glass, sehingga melepaskan ion fluorida. Ion ini merupakan kompleks metal fluoridaida, kemudian bereaksi dengan polianion untuk membentuk salt gel matriks. Ion $\mathrm{Al}^{3+}$ menyebabkan matriks resisten terhadap flow. ${ }^{15}$ Adhesi antara SIK dengan permukaan gigi dimulai dengan Polyalkenoic acid yang menempel pada email gigi dan kemudian berikatan dengan Phosphat dan Calcium pada email gigi. (Gambar 2). ${ }^{16}$

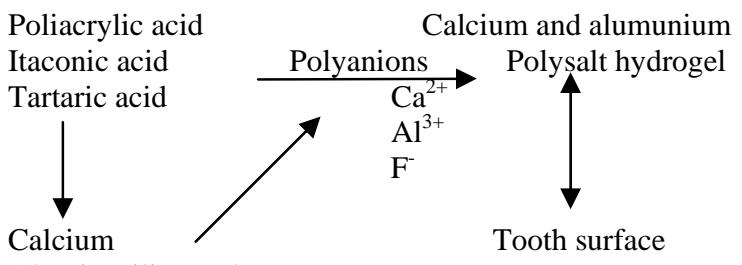

Aluminosilicate glass

Gambar 1. Reaksi setting Semen Ionomer Kaca. (Hickel. Various Forms of Glass Ionomer and Compomers.2001)

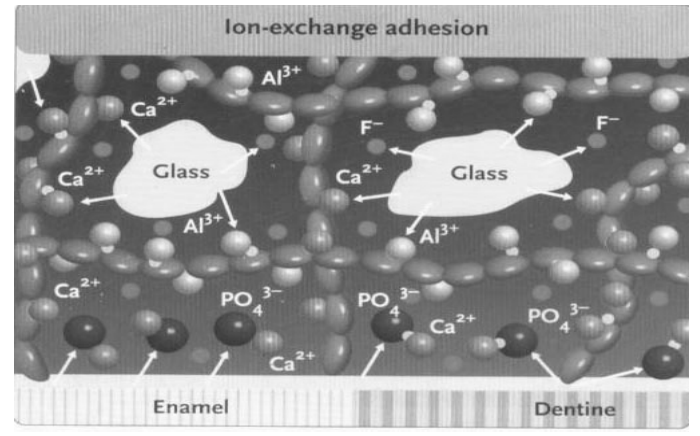

Gambar 2. Perpindahan ion antara SIK dengan struktur gigi. 16 
Reaksi mekanisme pelepasan fluorida tejadi secara 2 tahap, yaitu reaksi pelepasan fluorida dalam jangka pendek dan jangka panjang. Pada reaksi jangka pendek berhubungan dengan reaksi awal karena proses maturasi setelah setting terutama dalam 24 jam pertama, sedangkan pada minggu kedua hingga bulan kedua jumlah pelepasan fluorida telah menurun cukup banyak. Pada jangka panjang pelepasan fluorida relatif stabil dan sesuai dengan keseimbangan proses difusi. ${ }^{17,18}$

Kompomer sebagai bahan tumpat generasi baru kombinasi antara bahan tumpat sewarna gigi SIK dan komposit resin. Bahan ini merupakan pasta tunggal yang mengandung filler dan matriks, memerlukan light cured dan diformulasikan tanpa air. ${ }^{13,18}$ Presentase volume filler sekitar $42 \%$ hingga $67 \%{ }^{18}$ Kompomer mengandung fluoraluminosilicate glass sebagai filler yang dapat melepaskan fluorida. Sedangkan matriks dalam Kompomer adalah methacrylate polimer dan polyacid modified monomer. ${ }^{13,18}$

Kompomer memiliki keuntungan, antara lain tidak memerlukan mixing, sifat mekanis dan manipulasi yang lebih baik dibandingkan dengan SIK sebagai bahan restorasi. 13,18 Sedangkan kerugian yang dimiliki bahan ini yaitu tidak mengandung air dan tidak bersifat adhesif, hal ini berbeda dengan SIK. ${ }^{13}$ Kekuataan adhesinya memerlukan bonding agent. Bahan restorasi Kompomer berguna untuk pasien dengn resiko karies sedang, gig sulung, restorasi kelas I,II,III, V pada gigi anak dan lesi di servikal. ${ }^{13,18}$ Menurut data percobaan klinis, menunjukkan keberhasilan penggunaan bahan tumpat kompomer pada kavitas kelas III dan $\mathrm{V}$ pada gigi tetap dan gigi sulung. ${ }^{19}$ Kompomer yang beredar dipasaran salah satunya yaitu Dyract AP dari Dentsply. Kompomer memiliki retensi mikromekanis terhadap struktur email, dentin dan sementum akar. Retensi ini didapat setelah pemakaian kondisioner dan bahan adesif. Non Rinse Condisioner adalah produk kondisioner terbaru yang digunakan bersama dengan Prime \& Bond NT dan Kompomer. Penggunaan NRC tidak diperlukan lagi pencucian dengan air. Setelah kondisioner, digunakan bahan adesif untuk mendapatkan adesi kompomer dengan struktur gigi. $^{20,21}$

Reaksi pelepasan fluorida oleh bahan Kompomer diawali dengan reaksi setting. Reaksi setting yang utama yaitu reaksi polimerisasi dengan light cured, selain itu reaksi asan basa. ${ }^{8,10}$ Reaksi asam basa yang menghasilkan fluorida antara acidic monomer yang telah terpolimerisasi dengan glass filler yang mengandung fluorida, reaksi ini memerlukan adanya air dalam saliva. 7,13

Penelitian kandungan unsur fluorida dari bahan restorasi pada email dan dentin dengan berbagai metode telah banyak dilakukan. Dalam satu minggu pertama setelah penumpatan SIK dilakukan penelitian efek kariogenik. Dilakukan setelah satu minggu karena pada periode ini terjadi rerata penyerapan fluorida tertinggi. ${ }^{13}$ Penelitian kandungan unsur fluorida pada dentin yang dilakukan dengan metode Scanning Electron Microscope (SEM), Stereomicroscopic dan titrasi menunjukkan perbedaan antara tumpatan SIK dengan Kompomer. ${ }^{22}$ Bracket (2001) melaporkan bahwa sekunder karies yang terjadi pada restorasi SIK Fuji LC II lebih kecil dibandingkan dengan tumpatan Compoglass. ${ }^{22}$ Karantakis P (2000) melakukan penelitian insiden sekunder karies pada 2000 bahan restorasi yang mengandung fluorida dan hasilnya menunjukkan hanya terjadi 3\%. Pada penelitian ini sampel direndam dengan asam laktat $0,1 \%$. Hal ini menyebabkan terjadinya penurunan $\mathrm{pH}$ dan menyebabkan meningkatkan derajat kelarutan sehingga terjadi peningkatan pelepasan fluorida. ${ }^{17}$ Wibisono S (2003) dengan metode Energy Dispersive $X$-ray Spectrophotometry (EDS) menunjukkan bahwa, penyerapan fluorida pada email gigi sulung berbeda antara tumpatan SIK berbeda dengan Kompomer. ${ }^{23}$ Namun kandungan unsur fluorida pada email gigi tetap muda sampai saat ini belum diketahui. Energy Dispersive $X$-Ray Spectrophotometry (EDS) merupakan sistem yang ideal untuk mempresentasikan data $X$-ray sebuah specimen dan dapat diperoleh analisis baik secara kualitatif maupun kuantitatif. ${ }^{24}$ Tujuan penelitian ini adalah untuk mengetahui peningkatan kandungan unsur fluorida email gigi tetap muda setelah dilakukan tumpatan 
SIK dan Kompomer serta mengetahui perbedaan kandungan unsur fluorida email gigi tetap muda antara tumpatan SIK dan Kompomer dengan menggunakan EDS.

\section{Bahan dan Cara}

Gigi tetap muda premolar bebas karies dan stain yang dicabut untuk keperluan orthodonti dibersihkan dan disimpan dalam larutan Salin (NaCL 0,9\%). Gigi dibagi menurut axis gigi menjadi dua bagian dalam arah mesio distal. Tiap bagian kemudian dipreparasi pada sepertiga permukaan mesio oklusal dan disto oklusal menggunakan round bur no 801-9 dengan handpiece kecepatan tinggi dengan standar untuk semua gigi. Bagian pertama, pada kavitas diaplikasikan condisioner, ditumpat dengan SIK dan dilapisi dengan varnish. Bagian kedua, pada kavitas diaplikasikan dengan non rinse condisioner, bonding agent, ditumpat dengan Kompomer dan dilakukan light curing. Semua gigi premolar tetap muda dikembalikan ke dalam larutan salin, kemudian diperiksa kandungan fluorida pada hari ke tujuh.

Gigi dipersiapkan untuk diamati kandungan unsur fluorida pada email gigi tetap muda premolar. Pertama gigi dimounting dengan bahan akrilik. Setelah itu dilakukan coating dengan menggunakan tembaga, kemudian di vakum dan dianalisa dengan menggunakan EDS di jurusan Metarlugi Fakultas Tehnik UI. Pada tiap-tiap gigi tersebut ditentukan 6 area, 3 ditepi tumpatan dan 3 area di luar tumpatan. Pada penelitian ini dilakukan metode double blind. Kemudian disinari $X$-ray dengan arah tegak lurus permukaan sampel yang diteliti, sehingga didapatkan 189 data. Hasil yang diperoleh menunjukkan banyaknya kandungan unsur fluorida pada email gigi tetap muda premolar satu atas yang ditumpat dengan SIK dan Kompomer dengan alat EDS dalam satuan \%. Data yang diperoleh dianalisis dengan menggunakan uji $\mathrm{t}$ dengan batas kemaknaan = 0,05

\section{Hasil Penelitian}

Pengamatan kandungan fluorida yang dilakukan dengan alat EDS pada email gigi tetap muda antara tumpatan SIK dan Kompomer menunjukkan hasil berupa grafik. Grafik terdiri dari grafik diluar tumpatan, grafik di tepi tumpatan SIK dan grafik tepi tumpatan Kompomer.(Gambar 3)

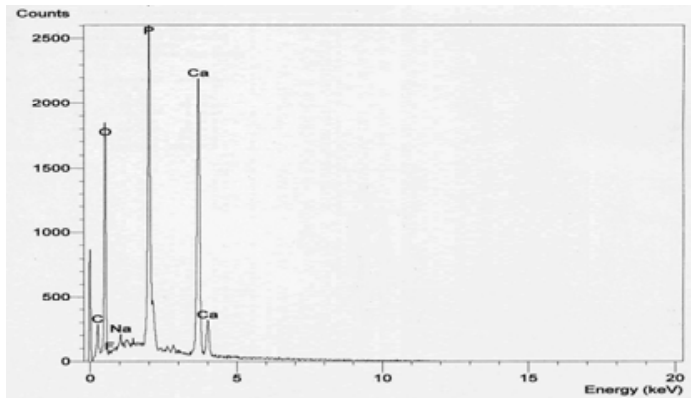

A
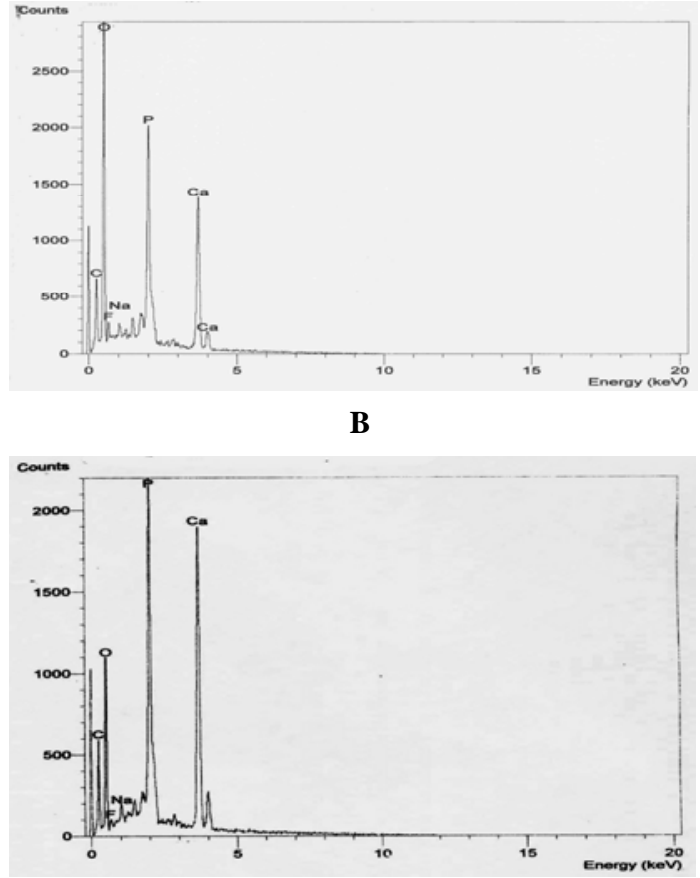

C

Gambar 3. Contoh Hasil pengamatan Kandungan fluorida pada email gigi tetap muda dengan menggunakan EDS A. Diluar tumpatan B. Ditepi tumpatan SIK C. Ditepi tumpatan Kompomer 
Eva Fauziah, Ismu S Suwelo, Hendarlin Soenawan

Tabel 1: Jumlah Sampel, Nilai Rerata, Simpang Baku, Kisaran dan Uji t dari Kandungan Fluorida pada Email Gigi Tetap Msuda antara Tumpatan SIK dan Kompomer.

\begin{tabular}{|c|c|c|c|c|c|c|c|c|}
\hline & \multicolumn{2}{|c|}{ F SIK (\%) } & \multicolumn{2}{|c|}{ F Kompomer(\%) } & \multicolumn{2}{|c|}{ F Tepi Tumpatan (\%) } & \multicolumn{2}{|c|}{ F peningkatan(\%) } \\
\hline & Di Luar & Di Tepi & Di Luar & Di Tepi & SIK 1 & Kompomer & SIK & Kompomer \\
\hline $\mathbf{N}$ & 21 & 21 & 21 & 21 & 21 & 21 & 21 & 21 \\
\hline Rerata & 1.58 & 4.60 & 1.58 & 3.31 & 4.60 & 3.31 & 3.02 & 1.73 \\
\hline SB & 0.46 & 1.24 & 0.46 & 1.09 & 1.24 & 1.09 & 1.34 & 1.23 \\
\hline Kisaran & $0.79-2.66$ & $2.75-8.03$ & $0.79-2.66$ & $1.72-6.31$ & $2.75-8.0$ & 3 1.72-6.31 & $0.91-6.5$ & $\begin{array}{ll}0 & 0.36-4.59\end{array}$ \\
\hline $\mathbf{T}$ & \multicolumn{2}{|c|}{-10.322} & \multicolumn{2}{|r|}{-6.423} & \multicolumn{2}{|r|}{3.705} & \multicolumn{2}{|c|}{3.705} \\
\hline df & \multicolumn{2}{|c|}{20} & \multicolumn{2}{|r|}{20} & \multicolumn{2}{|r|}{20} & \multicolumn{2}{|r|}{20} \\
\hline $\mathbf{p}$ & \multicolumn{2}{|c|}{$0.000^{*}$} & \multicolumn{2}{|r|}{$0.000 *$} & \multicolumn{2}{|r|}{$0.001^{*}$} & \multicolumn{2}{|c|}{$0.001 *$} \\
\hline
\end{tabular}

Keterangan: $\mathbf{N}=$ =Jumlah sampel, $\mathbf{S B}=$ Simpang Baku antara tumpatan SIK dan Kompomer tidak $\mathbf{t}=$ Nilai Uji, $\quad \mathbf{d f}=$ degree of freedom $\mathbf{p}=$ Nilai Signifikan *=bermakna

Pada Tabel 1, terlihat nilai rerata fluorida pada email gigi tetap muda di luar tumpatan (1.58\%) dibandingkan nilai rerata kandungan fluorida di tepi tumpatan SIK (4.60\%) menunjukkan peningkatan yang bermakna $(\mathrm{t}=-$ $10.322 \mathrm{p}=0.000)$. Nilai rerata fluorida pada email gigi tetap muda di luar tumpatan (1.58\%) dibandingkan nilai rerata kandungan fluorida di tepi tumpatan Kompomer (3.31\%) menunjukkan peningkatan yang bermakna ( $\mathrm{t}=-$ $6.423 \mathrm{p}=0.000)$. Nilai rerata peningkatan kandungan fluorida email gigi tetap muda yang ditumpat SIK (3.02\%) lebih tinggi dibandingkan dengan nilai rerata peningkatan Kompomer (1.73\%) dan bermakna ( $\mathrm{t}=3.705$ $\mathrm{p}=0.001)$. Tabel ini juga menunjukkan nilai rerata kandungan fluorida pada email gigi tetap muda yang ditumpat SIK lebih tinggi (4.60\%) dibandingkan nilai rerata yang ditumpat Kompomer (3.31\%) dan menunjukkan perbedaan yang bermakna $(\mathrm{t}=3.705 \mathrm{p}=0.001)$.

\section{Pembahasan}

Pada penelitian ini digunakan gigi tetap muda karena penyelesaian proses mineralisasi terjadi setelah 2-3 tahun erupsi, yaitu proses maturasi email. ${ }^{6}$ Sampel gigi yang digunakan bebas karies, agar tidak terjadi proses demineralisasi, sehingga hasil kandungan fluorida pada permukaan email gigi tetap muda

Bentuk kavitas, dalam kavitas, dan jenis bur yang digunakan tidak mempengaruhi hasil penelitian. Hal ini karena pada penelitian ini yang diteliti hanya besar kandungan unsur fluorida pada email gigi tetap muda. Sementara apabila diteliti mengenai penetrasi bahan tambal maka bentuk, dalam kavitas dan jenis bur perlu diperhatikan.

Pada penelitian ini, sampel direndam menggunakan larutan salin. Larutan salin memiliki $\mathrm{pH}$ netral, sehingga diharapkan dapat meminimalkan pengaruh yang ditimbulkan pada hasil penelitian. Penelitian lain yang menggunakan bahan perendam yang berbeda mungkin akan menunjukkan hasil kandungan unsur fluorida yang berbeda. Penelitian yang dilakukan Karantakis (2000) dengan menggunakan bahan perendam asam laktat $0,1 \%$ menunjukkan terjadinya penurunan $\mathrm{pH}$ dan menyebabkan meningkatkan derajat kelarutan sehingga terjadi peningkatan pelepasan fluorida. ${ }^{17}$ Dilakukan pada hari ke tujuh karena berdasarkan penelitian terdahulu, pelepasan fluorida tertinggi terjadi pada hari ke tujuh. $^{13}$

Pada penelitian ini unsur-unsur yang dapat terdeteksi selain fluorida (F), yaitu Carbon (C), Oksida (O), Natrium (Na), Phosfor (P), dan Calcium (Ca). Hal ini menunjukkan bahwa penelitian dengan menggunakan EDS dapat digunakan untuk menganalisa secara kualitatif. Seperti telah disebutkan sebelumnya bahwa EDS merupakan sistem yang ideal untuk mempresentasikan seluruh data X-ray sebuah 
spesimen dan dapat diperoleh analisis baik secara kualitatif maupun kuantitatif. ${ }^{24}$

Besar kandungan unsur fluorida pada penelitian ini antara tepi tumpatan SIK maupun Kompomer menunjukkan peningkatan dibandingkan diluar tumpatan. Hal ini disebabkan adanya penambahan kandungan unsur fluorida setelah dilakukan penumpatan.

Berdasarkan penelitian-penelitian sebelumnya telah menunjukkan bahwa pelepasan fluorida bahan SIK lebih tinggi dibandingkan Kompomer. Pelepasan fluorida dari bahan tumpat SIK yang tinggi menyebabkan peningkatan kandungan fluorida tepi tumpatan pada email gigi tetap muda yang ditumpat SIK lebih tinggi dibandingkan dengan Kompomer. Kandungan fluorida yang tinggi pada SIK, menyebabkan terjadinya resiko sekunder karies lebih kecil dibandingkan tumpatan Kompomer. Hal ini sesuai dengan penelitian yang dilakukan oleh Bracket (2001) bahwa sekunder karies yang terjadi pada restorasi SIK Fuji LC II lebih kecil dibandingkan dengan tumpatan Compoglass. ${ }^{22}$ Pada beberapa penelitian klinis lainnya juga menunjukkan insidens sekunder karies rendah pada restorasi SIK.

Hasil penelitian ini berbeda dengan penelitian yang dilakukan oleh Wibisono S. Hal ini disebabkan karena perbedaan sampel yang digunakan. Pada penelitian oleh Wibisono S sampel yang digunakan adalah gigi sulung. Hasilnya menunjukkan Pada penelitian oleh Wibisono S sampel yang digunakan adalah gigi sulung. Morfologi, histologi dan struktur permukaan email antara gigi sulung dan gigi permanen berbeda. Email gigi sulung kurang termineralisasi sehingga penyerapan unsurunsur mineral seperti fluorida menjadi lebih tinggi. ${ }^{23}$

\section{Kesimpulan}

Dari penelitian yang telah dilakukan dengan menggunakan EDS dapat disimpulkan bahwa bahwa ada peningkatan kandungan unsur fluorida pada email gigi tetap muda setelah dilakukan tumpatan SIK dan Kompomer. Peningkatan Kandungan unsur fluorida setelah dilakukan tumpatan SIK lebih tinggi dibandingkan dengan Kompomer. Penelitian ini juga menunjukkan ada perbedaan kandungan unsur fluorida pada email gigi tetap muda antara tumpatan SIK dan Kompomer. Kandungan unsur fluorida tumpatan SIK lebih tinggi dibandingkan Kompomer. Berdasarkan hasil penelitian ini dapat mendukung penggunaan klinis SIK pada gigi tetap muda. Selain kandungan fluorida masih perlu dilakukan penelitian lebih lanjut mengenai kandungan unsur yang lain pada email dan dentin gigi tetap muda dengan menggunakan SIK, Kompomer ataupun bahan restorasi lainnya.

\section{Daftar Pustaka}

1. Avery JK. Essential of Oral Histology and Embriology, St. Louis: Mosby.1992: 84-122.

2. Ten Cate AR. Oral Histology, Development, Structure, and Function, St Louis: Mosby.1980: 122-137,194-217.

3. Eront N, Kocatas N, Alpoz. A Comparative Study of Fluoride Uptake From Dentin Bonding Agents And Glass Ionomer Cements in Permanent and Primary Tooth Enamel. Quintessence Int. Juli 1999:30(7):496-500.

4. G Vermeersch, G. Leloup dan J Vreven. Fluoride Release From Glass Ionomer Cements, Compomer and Resin Composite. J.Op Oral Rehabilitation. Jan 2001, 28:26.

5. Mjor IA, Fejerskov Ole. Human Oral Embriology and Histology. $1^{\text {st }}$ ed. Munksgaard, Copenhagen.1986:81.

6. Soemartono SH. Masalah Karies Gigi Anak (Studi Pustaka). Buku Naskah KPPIKG-IX Fakultas Kedokteran Gigi Universitas Indonesia. 1991:393-4.

7. Thylstrup A, Fejerskov O. Textbook of Cariology, Copenhagen, Munksgaard. 1986:20 6-210,4.

8. Yap AUJ, Tan WS, Teo JC, Yap WY, Ong SB. Surface Texture of Resin-Modified Glass Ionomer Cements: Effects of Finishing/Polishi ng Systems. J.Op.Dent 2002; 27:381-6.

9. Yap AUJ, Chung SM, Chow WS, Tsai KT, Lim CT. Fracture Resistance of Compomer and Composite Restoratives. J.Op.Dent; 2004,291:29-34.

10. Demirci M, Ersev H, Ucok M. Clinical Evaluation A Polyacid-Modified Resin Composite (Dyract) in class III Cavities: Threeyear result. J.Op.Dent 2002; 27:223-30. 
11. Attar N, Onen A. Artificial Formed Caries-like Lesion Around Esthetic Restorative Materials. J. Ped. Dent 2002; 26:288-96.

12. Baum L, Mc Coy RB. Advanced Restorative Dentistry. Philadelphia. WB Saunders. 1984:558,72,265.

13. Davidson CL, Mjor IA. Advances in Glass Ionomer Cement. Chicago. Quintessence. 1999:18-28,86-97,121-6,179,201-22,270-5.

14. Hse KMY. Resin Ionomer Restorative Materials for Children: A Review. Aust Dent J 1999; 44 (1) : 1-11.

15. Hickel RA, Folwaczny M. Various Forms of Glass Ionomer and Compomers. J. Op.Dent 2001; 6: 177-90.

16. Mounth GJ, Hume WR. Preservation and Restoration of Tooth Structure. Mosby. St. Louis.2002:78-9.

17. Karantakis $\mathrm{P}$, Antoniades $\mathrm{MH}$, Pahini ST et al: Fluoride Release from three Glass Ionomers, A Compomer and a Composite Resin in Water, Artificial Saliva and Lactic Acid. J.Op.Dent 2000; 25: 20-5.
18. Craig Rg, Power JM. Restorative Dental Materials. $11^{\text {th }}$ ed. Mosby. St. Louis.2002:55,15 2,211-17.313,598-99,614-16.

19. Walmsley AD, Walsh TF, Burket TFJ. Restorative Dentistry. $1^{\text {st }}$ ed. Churchill Livingstone. 2002:70-2.

20. Meyer JM, Cattani-Lorente MA, Dupuis V. Compomers: between glass ionomer cements and composite. Biomaterial 1998,9: 529-39.

21. Mc Cabe JF. Resin modified glass ionomers. Biomaterials. 1998,19:521-7.

22. Bracket WWW, Browning WD, Ross JA, et al. Two Year Clinical Performance of A Acid Modified Resin Composite and A Resin Modified Glass Ionomer Restorative Material. J.Op.Dent 2001; 26: 12-6.

23. Wibisono S. Perbedaan Penyerapan Fluor Pada Email Gigi Sulung Antara Tumpatan Semen Ionomer Kaca Dan Kompomer. Jakarta: Pendidikan Dokter Gigi Spesialis Ilmu Kedokteran Gigi Anak Fakultas Kedokteran Gigi Universitas Indonesia. 2003:26.

24. Goodhew PJ, Humprey FJ. Electron Microscopy and Analysis $2^{\text {nd }}$ ed, London: Taylor \& Francis. 1998:160-6. 